\title{
Content fo copper, zinc, lead, cadmium and mercury in muscle, liver and kidney of Finnish cattle
}

\author{
Ruth Stabel-Taucher, Esko Nurmi, and Eeva Karppanen \\ State Veterinary Medical Institute, Helsinki
}

\begin{abstract}
A total of 120 normal slaughter cows were analyzed with respect to $\mathrm{Cu}$, $\mathrm{Zn}, \mathrm{Pb}, \mathrm{Cd}$ and $\mathrm{Hg}$ in muscle, liver and kidney. The cows orginated from 6 different slaughter-houses throughout the country. Imported cow livers, represented by 10 samples from Australia, 10 from Poland and 15 from Ireland, were also analyzed for comparison with the Finnish material.

The Cu content in the Finnish animals turned out to be relatively low. The imported samples had even lower contents. There seemed to be no correlation between the $\mathrm{Cu}$ contents in muscle, liver and kidney. Statistical tests established that the mean $\mathrm{Cu}$ content in livers from Oulu was significantly higher than most of the others at the $5 \%$ level.

The $\mathrm{Zn}$ determinations revealed the highest amounts in the muscle. No correlation between the contents in muscle, liver and kidney was shown. The animals from Seinäjoki had the highest $\mathrm{Zn}$ contents, significantly different from most of the others. The imported livers did not differ much from the domestio ones as regards $\mathrm{Zn}$ content. The same was true for the $\mathrm{Pb}$ content. The correlation coefficients of $\mathrm{Pb}$ in muscle, liver and kidney were low. The animals from Kouvola contained the highest amounts of $\mathrm{Pb}$, and the mean $\mathrm{Pb}$ content of these animals' kidneys was significantly different from all the others.

The Cd content was highest in the animals from Turku. A good correlation was observed between the $\mathrm{Cd}$ contents in liver and kidney. The $\mathrm{Cd}$ content of the imported livers was of the same order as that of the Finnish ones. No correlation was found between the $\mathrm{Zn}, \mathrm{Pb}$ and $\mathrm{Cd}$ contents.

The amounts of $\mathrm{Hg}$ in Finnish cattle were very low, especially so in animals from the North of Finland. The $\mathrm{Hg}$ content of the imported samples was of the same order as the figures recorded from the South of Finland.
\end{abstract}

\section{Introduction}

In the group of heavy metals we primarily find the essential metals that are needed in well balanced amounts for the optimal development of man, animal and plants. Among these elements are counted iron, cobalt, copper, chromium, manganese, molybdenum, nickel, and zinc. However, several of these essential metals may have a poisonous effect when consumed in too high amounts (RINGENA 1971, Tolle et al. 1973). Some animal species are more sensitive than others. Van ULSEN (1973) describes chronical copper poisoning 
in sheep that had eaten grass from a field fertilized with liquid manure from swine fed on $\mathrm{Cu}$ fortified feed.

However, in the last years most of the attention has been directed towards the elements lead, cadmium and mercury. These elements are not considered to be essential, and are the origin of many incidents of poisoning (FrIBERG et al. 1974, Chrisholm 1971, Clarkson 1972). They have existed in our environment since ancient times, but with the industrialization a shifting in the pattern of occurrence has found place. This has led to extreme accumulations in certain places and thereby to elevated concentrations of heavy metals in certain foods. Contamination with heavy metals in foods may also arise from agricultural technology, mines and food processing. In the last few years many publications from various countries have appeared giving information about the content of heavy metals in foods. (Hecht 1973, Kirkpatrick and Coffin 1973, Schelenz and Diehl 1973, Beckman et al. 1974, and Bramsö et al. 1974).

\section{Material and Methods}

The purpose of the present work was to gather information concerning the content of heavy metals in Finnish cattle. Samples from 20 cows were collected from 6 slaughterhouses in different geographical locations in order to establish whether the contamination was heavier in the Southern than in the Northern parts of the country. Another aim was to find out whether regions with closely adjacent industry, mines or heavy traffic were more strongly contaminated than other regions presenting no such pollution risk factors. In order to establish whether there was any marked difference between Finnish and imported cow livers, 10 Australian, 10 Polish, and 15 Irish liver samples were analyzed for comparison.

The six slaughterhouses were instructed to take approximetely $100 \mathrm{~g}$ of the pectoral muscle, liver and kidney of 20 normal slaughter cows from different producers. The samples were enclosed in polyethylene bags, cooled down and transported by the fastest possible route to our laboratories. Here they were kept at $-20^{\circ} \mathrm{C}$ up to the day of analysis. The samples were then thawed and the fat, if any, was removed. From the kidneys the cortex was used.

For the determination of $\mathrm{Pb}, \mathrm{Cd}, \mathrm{Zn}$ and $\mathrm{Cu}, 10 \mathrm{~g}$ of the homogenized material was weighed into quartz dishes and dried on a water bath for about 3 hours. The samples were then placed on an asbestos screen and pre-ashed over a low flame until no more smoke emerged. Finally, they were ashed at $450^{\circ} \mathrm{C}$ over night. After cooling, $0.5 \mathrm{ml}$ of conc. $\mathrm{HNO}_{3}$ was added together with a small quantity of water. This was followed by drying on the water bath and renewed ashing at $450^{\circ} \mathrm{C}$, for 3 hours. The ash was dissolved in 0.5 $\mathrm{ml}$ of conc. $\mathrm{HNO}_{3}$, diluted with deionized water, filtered into a $50 \mathrm{ml}$ volumetric flask and filled up to the mark. After suitable dilutions had been made, the content of $\mathrm{Pb}, \mathrm{Cd}, \mathrm{Cu}$ and $\mathrm{Zn}$ was determined with the aid of atomic absorption spectrometry (PERKIN-Elmer 303, fitted with a graphite furnace and a deuterium background corrector). The instrument was operated according to the manufacturer's manual. $\mathrm{Cu}$ and $\mathrm{Zn}$ were determined in the flame, and $\mathrm{Pb}$ and $\mathrm{Cd}$ in the furnace. 
For the determination of $\mathrm{Hg}, 10 \mathrm{~g}$ of the material was freeze-dried over night. About $0.5 \mathrm{~g}$ of this material was then subjected to combustion in an oxygen flask containing sulphuric acid (HELmineN at al 1966), and $\mathrm{Hg}$ was determined from the absorption solution with the aid of a Coleman Mercury Analyzer MAS-50, following the operating directions of Coleman Instruments.

The statistical treatment of the data obtained consisted of calculation, with a Compucorp 445 Statistician, of the mean value $(\bar{x})$, standard deviation $\left(\mathrm{SD}_{\mathrm{n}-1}\right)$ and correlation coefficients $(\mathrm{r})$ between the metal contents of muscle and liver, liver and kidney, kidney and muscle. The correlation coefficients between $\mathrm{Zn}$ and $\mathrm{Pb}, \mathrm{Pb}$ and $\mathrm{Cd}$, and $\mathrm{Cd}$ and $\mathrm{Zn}$ were also calculated. The results were tested for significant differences between the metal contents in cattle originating from different regions of the country by Duncan's New Multiple Range Test (Steel, and Torrie 1960).

\section{Results}

The results of the $\mathrm{Cu}, \mathrm{Zn}, \mathrm{Pb}$ and $\mathrm{Cd}$ determinations in Finnish cattle are seen in Table 1. The results of the $\mathrm{Hg}$ determinations are given in Table 2 . The sensitivity of the Coleman Mercury Analyzer MAS-50 is equal to or better than $0.01 \mu \mathrm{g}$ of $\mathrm{Hg}$. As it soon became evident that our samples contained only small amounts of mercury, we contented ourselves with analyzing only the samples of about 10 cows from each slaughterhouse, and merely those of their muscles and livers. The result of Duncan's New Multiple Range Test is shown in Table 3 , while Table 4 shows the results of the metal determinations with the imported livers. The correlation between the metals $\mathrm{Zn}, \mathrm{Pb}$, and $\mathrm{Cd}$ are seen in Table $\mathbf{5}$.

\section{Discussion}

1-2 $\mathrm{mg}$ of $\mathrm{Cu}$ per day is considered the necessary daily intake (ToLLE et al. 1973), and this also agrees with the average value $(2.1 \mathrm{mg}$ daily intake/ person) obtained from diet surveys in Canada (Somers 1974). Chronic Cu poisoning of humans has not been described in the literature, but chronic poisoning of animals may occur in the neighbourhood of copper mines and of industry where contamination of the water and fields may occur. The content of $\mathrm{Cu}$ in the feed usually differs widely. A content of less than 10-12 ppm $\mathrm{Cu}$ in the feed may result in $\mathrm{Cu}$ deficiency in cows (Tolle et al. 1973). Our $\mathrm{Cu}$ anlyses showed high variances, especially in the livers, where $\mathrm{Cu}$ accumulates. By comparing our results with those reported in the literature, we found that ours were lower. Hecht (1973) reports the mean value of $\mathrm{Cu}$ in muscle to be $3.25 \mathrm{ppm}(\mathrm{SD}=3.74, \mathrm{~N}=30)$. Our corresponding value was $0.88 \mathrm{ppm}$ $(\mathrm{SD}=0.38, \mathrm{~N}=120)$. Our liver samples also showed a lower content of $\mathrm{Cu}(\overline{\mathrm{x}}=56.65, \mathrm{SD}=40.05, \mathrm{~N}=120)$ than is considered normal for milkcows in West Germany, viz. 100-200 ppm (Rosenberger, 1970). Biochemisches Taschenbuch, 1964, reports a value of $85 \mathrm{ppm}$ in liver of cattle. The imported livers (Australia $22.21 \mathrm{ppm}$, Poland $22.10 \mathrm{ppm}$, and Ireland $8.81 \mathrm{ppm} \mathrm{Cu}$ ) contained even less $\mathrm{Cu}$ than the Finnish ones. 


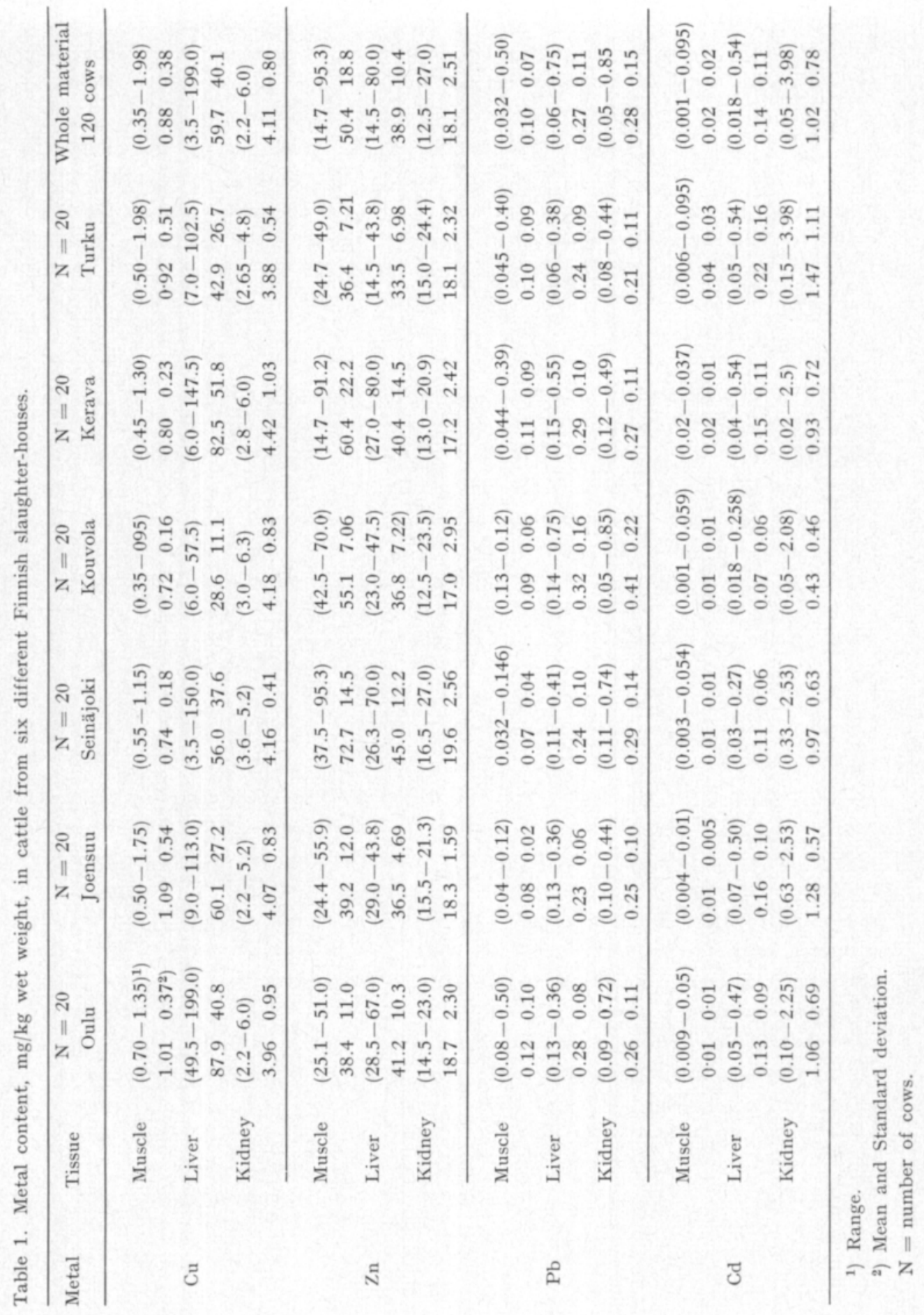




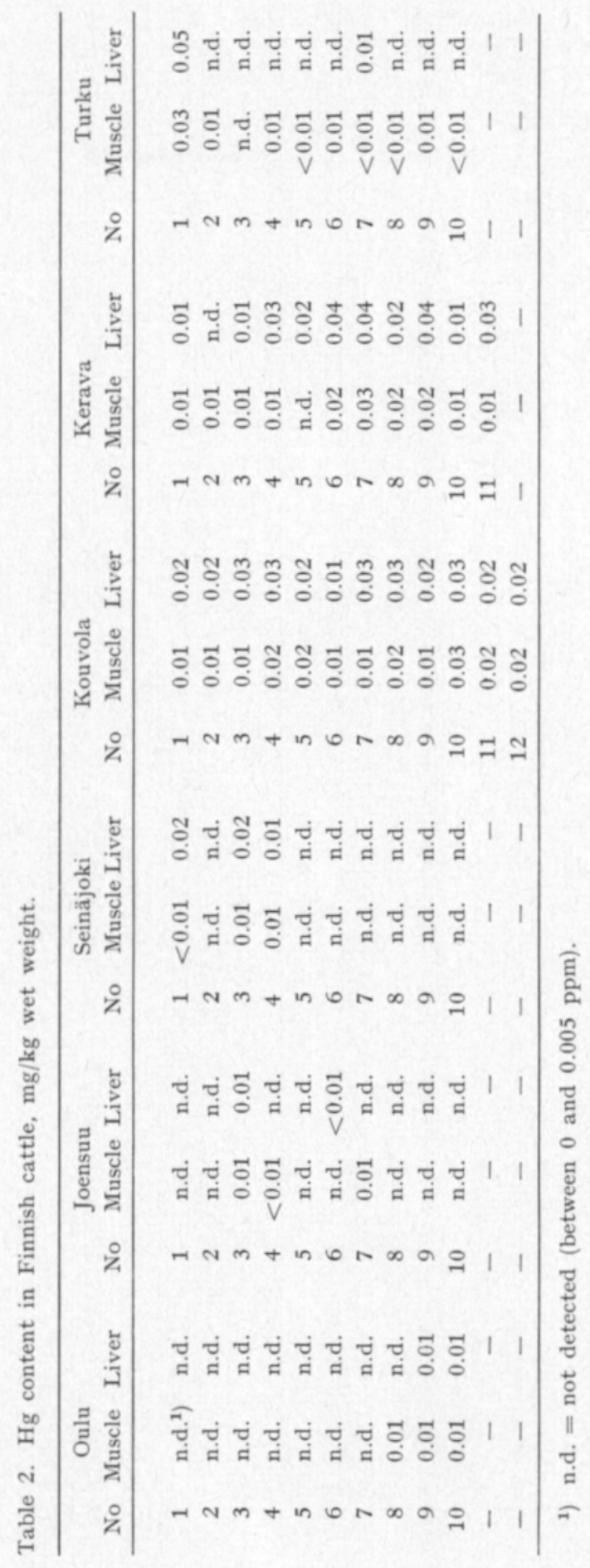




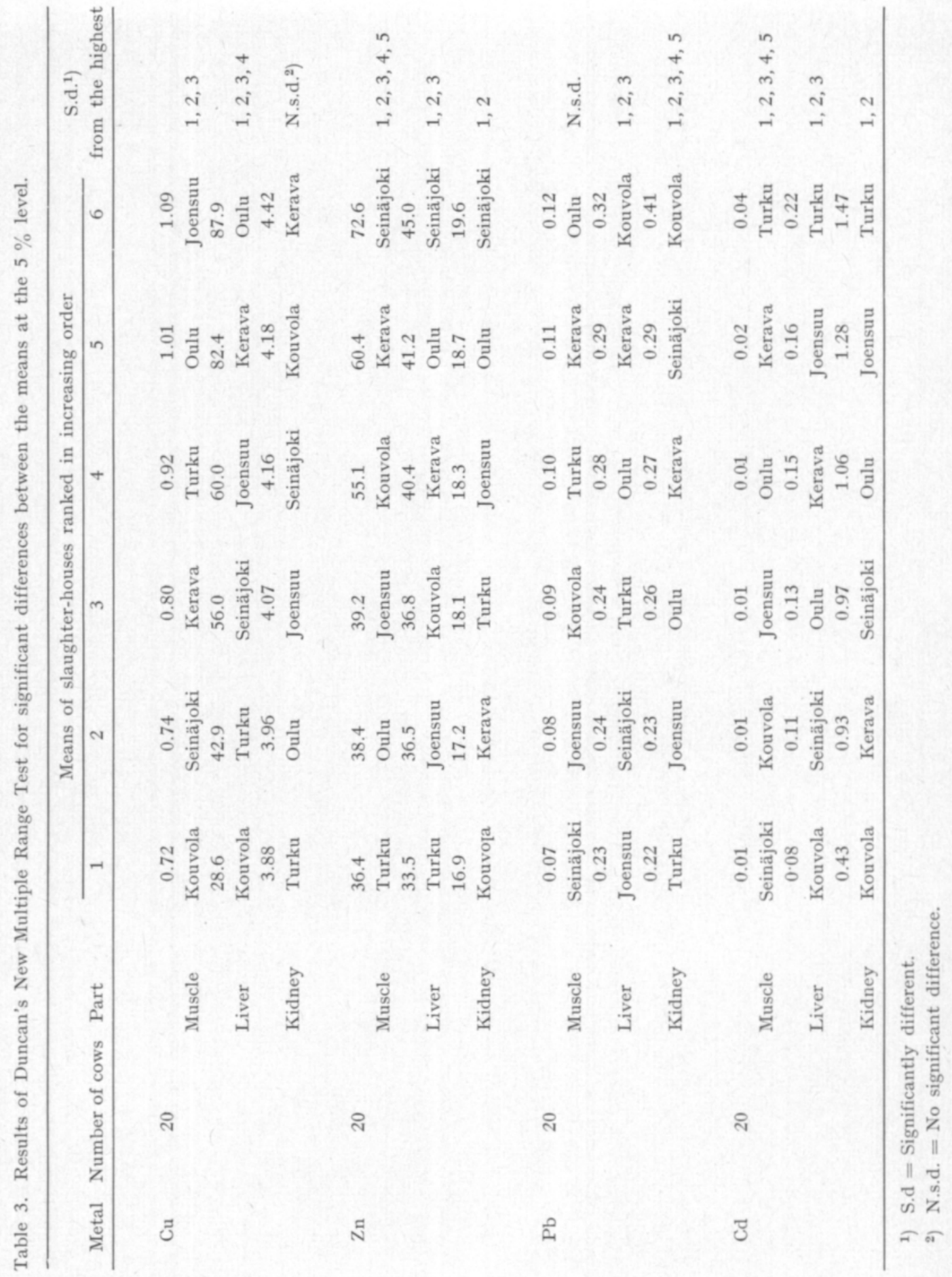


Table 4. Contents of $\mathrm{Cu}, \mathrm{Zn}, \mathrm{Pb}, \mathrm{Cd}$, and $\mathrm{Hg} \mathrm{mg} / \mathrm{kg}$ wet weight in Finnish and imported liver.

\begin{tabular}{|c|c|c|c|c|c|c|c|c|c|c|}
\hline \multirow[b]{2}{*}{ Country } & \multirow[b]{2}{*}{$\begin{array}{c}\text { No of } \\
\text { samples }\end{array}$} & \multicolumn{2}{|c|}{$\mathrm{Cu}$} & \multicolumn{2}{|c|}{$\mathrm{Zn}$} & \multicolumn{2}{|c|}{$\mathrm{Pb}$} & \multicolumn{2}{|c|}{$\mathrm{Cd}$} & \multirow{2}{*}{$\frac{\mathrm{Hg}}{\bar{x}}$} \\
\hline & & $\bar{x}$ & SD & $\bar{x}$ & SD & $\bar{x}$ & SD & $\bar{x}$ & SD & \\
\hline Finland & 120 & 59.65 & 40.05 & 38.88 & 10.37 & 0.27 & 0.11 & 0.14 & 0.11 & $\begin{array}{r}\left.0.02^{1}\right) \\
\left.<0.01^{2}\right)\end{array}$ \\
\hline Australia & 10 & 22.21 & 14.85 & 33.94 & 8.22 & 0.23 & 0.11 & 0.06 & 0.05 & 0.03 \\
\hline Poland & 10 & 22.10 & 22.25 & 35.70 & 6.27 & 0.37 & 0.14 & 0.12 & 0.11 & 0.04 \\
\hline Ireland & 15 & 8.81 & 11.16 & 44.03 & 19.35 & 0.29 & 0.09 & 0.14 & 0.11 & $<0.01$ \\
\hline
\end{tabular}

\footnotetext{
1) $=$ Southern Finland.

$\left.{ }^{2}\right)=$ Northern Finland

$\overline{\mathrm{x}}=$ mean.

$\mathrm{SD}=$ standard deviation
}

Table 5. Correlation coefficients (r) between the metals $\mathrm{Zn}, \mathrm{Pb}$, and $\mathrm{Cd}$.

\begin{tabular}{rrrrrr}
\hline$r$ & No of samples & Muscle & Muscle & \multicolumn{1}{c}{ Liver } & \multicolumn{1}{c}{ Kidney } \\
\hline & & & & & -15 \\
$r_{1}$ & $(\mathrm{Zn}-\mathrm{Pb})$ & 120 & -0.11 & 0.17 & -0.15 \\
$\mathrm{r}_{2}$ & $(\mathrm{~Pb}-\mathrm{Cd})$ & 120 & 0.12 & -0.10 & -0.15 \\
$\mathrm{r}_{3}$ & $(\mathrm{Cd}-\mathrm{Zn})$ & 120 & -0.17 & -0.05 & 0.30 \\
\hline
\end{tabular}

Table 3 shows that the $\mathrm{Cu}$ contents in cow livers from Oulu $(\mathrm{x}=\mathbf{8 7 . 9 0}$ ppm) were higher than and significantly different from the values referring to four other locations. Kerava also showed high values $(\mathrm{x}=82.44)$. It is hard to say whether this is due to differences in the composition of the feed or to a higher age of the cows.

The average daily intake of $\mathrm{Zn}$ is $16.9 \mathrm{mg}$ per person, according to the above mentioned Canadian diet survey (SOMERs 1974), and this agrees well with what is considered necessary (SCHROEDER et al. 1967). Zn poisoning of humans is rare, but it may occur in connection with food that has been kept in zink containers at a low pH (Tolle et al. 1973). Also in animals this type of poisoning is rather infrequently described in the literature, but it may occur in the presence of zink ores and through contamination of the feed with $\mathrm{Zn}$ compounds (RINGENA 1971).

From our results it appears that the highest $\mathrm{Zn}$ amounts are found in the muscle $(\vec{x}=50.35)$. The mean value of the livers was 38.88 and that of the kidneys 18.14. These are in good agreeement with values reported (НEcHT 1973, Ringena 1971). Duncan's multiple range test revealed that the $\mathrm{Zn}$ content in the muscle of the animals from Seinäjoki was significantly different from all the others. This might partly be due to the fact that there is a zinc mine in the neighbourhood. The value $(\bar{x}$ in muscle $=72.68)$ is not abnormally high however. Ringena (1971) reports the mean $\mathrm{Zn}$ value in muscle to be 46.0-50.4 and Неснт (1973), $77.9 \mathrm{ppm}$. The $\mathrm{Zn}$ content of the imported livers did not differ much from that of the domestic ones. 
Cadmium is related to zinc in the geosphere and biosphere, and therefore the concern for zinc is intimately connected with that for cadmium (SCHROEDER et al. 1967). In human kidneys cadmium is bound by a protein,metallothioneine, which also contains zinc, (KÄGI and VALLE 1960), and cadmium apparently competes with zinc at the same binding sites (Pulido et al. 1966). Cadmium is obtained as a byproduct in zinc conversion. Introduction of cadmium into the environment may take place in the air or in water. Cadmium pollution has become a problem of current interest after the occurrence of chronic cadmium poisoning (Itai-Itai disease) in the population of certain rural areas in Japan.

Estimates of the daily intake of cadmium, based on data of cadmium concentrations in food, have been made in several countries (NordBERG 1974). The results range from 25 to $60 \mu \mathrm{g} /$ day per person. This may be compared with the tolerable weekly intake of 400 to $500 \mu \mathrm{g}(70 \mu \mathrm{g} /$ day $)$ proposed by the joint FAO/WHO Expert Committee on Food Additives (1972). Cadmium in the air normally contributes very little to the daily intake in non-polluted areas, but in the neighbourhood of Cd-emitting factories the air may cause $4 \mu \mathrm{g}$ /day to be inhaled (NordBerg 1974). Smoking 20 cigarrettes per day probably causes an inhalation of $2-4 \mu \mathrm{g} /$ day (NoRDBERG 1974).

Our results agree well with those published in other countries (Nordberg 1974). We found the mean value of $\mathrm{Cd}$ in muscle of cattle to be $0.02 \mathrm{ppm}$. The U.K. reports 0.03 , and West Germany 0.06 . In liver we found $0.14 \mathrm{ppm}$; Sweden reports 0.11, Czechoslovakia 0.16, the U.K. 0.05, and the U.S.A. 0.20. Among the imported livers analyzed, we found those from Australia to have the lowest content (0.06). In kidney we found $1.02 \mathrm{ppm}$, while Sweden reports 0.62, the U.K. 0.5, the U.S.A. 0.5, and Czechoslovakia 1.6.

Duncan's multiple range test showed that the $\mathrm{Cd}$ content in the muscle of cattle from the slaughterhouse of Turku was significantly different from the rest of the figures. The inference appears reasonable that the area around Turku would seem to be more strongly polluted with $\mathrm{Cd}$ than other areas in Finland; since we lack information of the animals' age, we cannot draw this conclusion directly, however. From the following table composed of data from a Swedish publication (BECKMAN et al. 1974) a very obvious dependence of the cadmium content on age is apparent.

\begin{tabular}{cccccc} 
Animal & Number & \multicolumn{1}{c}{ Age } & Cd in liver & Cd in kidney & \multicolumn{1}{c}{$\begin{array}{l}\text { Ref } \\
\text { Cattle }\end{array}$} \\
& 9 & $0.21(0.12-0.33)$ & $0.06(<0.02-0.17)$ & $0.25(<0.02-0.75)$ & $\begin{array}{l}\text { Beckman } \\
\text { et al. } \\
(1974)\end{array}$ \\
& 28 & $2.9(0.42-12)$ & $0.11(0.03-0.33)$ & $0.62(0.11-3.2)$ & $\begin{array}{l}\text { Present } \\
\text { study }\end{array}$
\end{tabular}

The calculated correlation coefficients showed that in most cases there is good correlation between the amount of $\mathrm{Cd}$ in liver and kidney. This correlation was unequivocally established for the element $\mathrm{Cd}$ only. From the table showing the correlation coefficients of the metal contents (Table 5) we may conclude that there is no correlation between the amounts of $\mathrm{Zn}, \mathrm{Cd}$ and $\mathrm{Pb}$ in the cows analyzed. 
Man's total lead exposure is normally made up by food, water, and ambient air (HERnBERg 1973) and amounts to about $400 \mu \mathrm{g} /$ day, distributed as follows (Underwood 1971): from food $220 \mu \mathrm{g} /$ day, from water $100 \mu \mathrm{g} / \mathrm{day}$, and by inhalation $80 \mu \mathrm{g} /$ day. Chronic lead poisoning as a consequence of contaminated drinking water or food is known since long (CHRISHOLM 1971). The joint FAO/WHO Expert Committee proposes a provisional tolerable weekly intake of $3000 \mu \mathrm{g}$ of lead per person $(430 \mu \mathrm{g} /$ day $)$. The results of total diet studies in industrialized countries suggest an intake of lead of the order of $200-300 \mu \mathrm{g}$ per person per day. In general, the content of lead present in food, according to an English survey (DalgaARD-Mikkelsen 1974), is less than $0.2 \mathrm{ppm}$ and that in water and milk is less than $0.01 \mathrm{ppm}$. Неснт (1973) reports for muscle of cattle $(\mathrm{N}=30)$ a mean value of $0.094 \mathrm{ppm} \mathrm{Pb}$. This agrees well with our results, as our corresponding value was $0.10(\mathrm{~N}=120)$. The following table has been compiled from figures taken from a Swedish publication (BECKMAN et al. 1974) and from our own results.

\begin{tabular}{|c|c|c|c|c|c|}
\hline Animal & Number & Age & $\mathrm{Pb}$ in liver & $\mathrm{Pb}$ in kidney & Ref \\
\hline Cattle & 9 & $0.21(0.12-0.33)$ & $0.33(0.2-0.7)$ & $0.32(0.2-0.4)$ & Beckman \\
\hline , & 28 & $2.9(0.42-12)$ & $0.40(0.2-2.8)$ & $0.59(0.2-5.7)$ & (1974) \\
\hline , & 120 & Unknown & $0.27(0.06-0.75)$ & $0.28(0.1-0.85)$ & $\begin{array}{l}\text { Present } \\
\text { study }\end{array}$ \\
\hline
\end{tabular}

As can be seen from the table, the amount of $\mathrm{Pb}$ in liver and kidney is dependent on age, and it accomulates more strongly in kidney than in liver.

The statistical test of the results of this study showed that the $\mathrm{Pb}$ content in kidney of cattle from Kouvola was significantly different from that of all the other slaughter-houses. Whether this is accountable to higher age of the animals or to a higher pollution of the environment at Kouvola, is difficult to ascertain. Of the imported livers analyzed, only those from Poland ( $0.37 \mathrm{ppm})$ showed a worth while difference from the Finnish findings $(0.27 \mathrm{ppm})$, but they were not abnormally high.

According to a Canadian diet survey (Somers 1974), the average daily intake of mercury is $13 \mu \mathrm{g}$ per person, and according to a German survey it is 12.3 $\mu \mathrm{g}$ (Schelenz und Diehl 1973). The FAO/WHO Expert Committee (1972) establishes a provisional tolerable weekly intake of $300 \mu \mathrm{g}$ of total mercury (43 $\mu \mathrm{g} /$ day), of which no more than $200 \mu \mathrm{g}$ should be present as methyl mercury. The safety margin seems to be wide enough in normal cases. Epidemic outbreaks of mercury poisoning of fishermen's families in Japan are well known. Also grain treated with methyl mercury has caused a major outbreak of poisoning among the population of the Middle East in 1972. Poisoning of swine fed with mercury-treated grain has been reported (DALGAARD-MikKELSEN 1974). Normally, only fish constitutes a problem in human nutrition, since vegetables and meat contain small amounts of mercury only.

As can be seen from Table 2, most of the samples from Oulu, Joensuu, and Seinäjoki, that is from North and Middle Finland, were below the detection limit of our method, which is about $0.005 \mathrm{ppm}$. The samples from South Finland showed higher contents: Kouvola about $0.02 \mathrm{ppm}$ in muscle and liver, 
Kerava $0.01 \mathrm{ppm}$ in muscle and 0.02 in liver, and Turku just between the detection limit and $0.01 \mathrm{ppm}$. Of the imported livers, those from Ireland showed the lowest content, below $0.01 \mathrm{ppm}$. The Australian livers had a mean value of $0.03 \mathrm{ppm}$, and those from Poland $0.04 \mathrm{ppm}$.

Provided the food habits are largely the same in Finland and in other industrialized countries where total diet surveys have been performed, there should be no risk of $\mathrm{Cu}$ and $\mathrm{Zn}$ deficiency. Nor should there exist any danger of exeeding the provisional tolerable weekly intakes of $\mathrm{Pb}, \mathrm{Cd}$ and $\mathrm{Hg}$ through a normal consumption of meat, liver and kidney from Finnish and imported cattle.

Acknowledgement. The authors wish to express their gratitude to M.Sc. Outi Lohi for help and advice in the statistical treatment of the data.

\section{REFERENCES}

Beckman, I., Haegglund, J., Lundström, H., Sark, H. \& Slorach, S. 1974. Kadmium och bly i njure och lever från slaktdjur. Vår Föda 26,$4 ; 70-75$.

Biochemisches Taschenbuch. 1964. H. M. Rauen, Zweiter Teil. Springer Verlag.

Bramsö, S., Funder-Schmidt, B., Hansen, J. C. \& Ulrich, G., 1974. Måling of kviksölv i levnedsmidler. Medlemsblad for den danske dyrlaegeforening 57, 8:333-340.

Chrisholm, J. J. Jr. 1971. Lead poisoning. Scient. Amer. 224:15-23.

Clarkson, T. W. 1971. CRC Critical Rev. Tox. March 203.

DalgaARd-Mikkelsen, S. 1974: Ökotoksikologi. Medlemsblad for den danske dyrlaegeforening 57: 4-8.

Friberg, L., Piscator, M., Nordberg, G. \& Kjellström, T. 1974. Cadmium in the environment. 2nd ed., CRC Press, Cleveland, Ohio.

Неснт, H. 1973. Untersuchungen über Spurenelemente im Fleisch. Arehiv für Lebensmittelhygiene $24,11: 255-258$.

Helminen, M., Karppanen, E. \& Henriksson, K. V. 1966. „Inverkan av betningsmedel innehållande metoxyetylmerkurisilikat på fasaner under försöksförhållanden». Finsk Vet. Tidskr. 72: $381-389$.

Hernberg, S. 1973. Lead. In the book Occupational Medicine, Principles and Practical Applications. Ed. Carl Zenz. Yearbook Medical Publishers, Boston, in press.

Joint FAO/WHO Expert Committee on Food Additives. 1972. A Sixteenth Report, Wld, Hlth Org. Tech. Rep. Ser. No 505.

Kirkpatric, D. C. \& Coffin, D. E. 1973. Cadmium, lead, and mercury content of various cured meats. J. Sci. Fd. Apric. 24: 1595-1598.

KägI, J. H. R. \& VAllee, B. L. 1960. Metallothionein: A cadmium and zinc containing protein from equine renal cortex». J. Biol. Chem. 235: 3460 .

NordBerg, G. F. 1974. Health hazards of environmental cadmium pollution. Ambio 3,2: 55-65.

Pulido, P., Kägi, J. H. R. \& Vallee, B. L. 1966. Isolation and some properties of human metallothionein. Biochemistry 5: 1768.

Ringena, H. 1971. Die Zinkvergiftung des Rindes. Schriftumsübersicht. Inaug.-Diss. Tierärztliche Hochschule Hannover.

Rosenberger, G. 1970. Krankheiten des Rindess. Verlag P. Parey, Berlin und Hamburg. SCHELENZ, R. \& DieHL, J. F. 1973. Quecksilber in Lebensmitteln, Untersuchungen an täglicher Gesamtnahrung. Z. Lebensm. Unters. Forsch. 153:151-154. 
Schroeder, H. A., Nason, A. P., Tipton, I. H. \& Balassa, J. J. 1967. Essential trace metals in man: Zinc, relation to environmental cadmium. J. Chron, Disease 20: 179.

Somers, E. 1974. The toxic potential of trace element in foods. J. Fd. Sc. 39: 215-217.

Steel, R. G. D. \& Torrie, J. H. 1960: Principles and procedures of statistics with special reference to the biological sciences. Mc. Graw-Hill Book Comp.

Tolle, A., Heeschen, W., Blutgen, A., Hamann, J. \& Reichmuth, J. 1973. Toxische Spurenstoffe und unerwünschte Konzentrationen von Spurenelementen. Kieler Milchwissenschaftliche Forsch. berichte 25,4:478-508.

Ulsen, F. W. van. 1973. Sheep, swine and copper. Neth. J. Vet. Sci 5: 113-115.

Underwood, E. J. 1971. Trace Elements in Human and Animal Nutrition. Academic Press.

New York and London.

SELOSTUS

\title{
Kupari, sinkki, lyijy, kadmium ja elohopea suomalaisten nautojen lihassa, maksassa ja munuaisissa
}

\author{
Ruth Stabel-Taucher, Esko Nurmi ja Eeva Karppanex \\ Valtion eläinlääketieteellinen laitos, Helsinki 55
}

Tutkimusta varten hankittiin kuudesta eri teurastamosta (Oulu, Joensuu, Seinäjoki, Kouvola, Kerava ja Turku) lihas-, maksa- ja munuaisnäytteet 20 naudasta. Metallipitoisuudet määritettiin yhteensä 120 naudan näytteistä. Vertailuksi analysoitiin 10 australialaista, 10 puolalaista ja 15 irlantilaista maksanäytettä. Tuloksista laskettiin keskiarvo, standardipoikkeama ja tutkittujen näytteiden sekä määritettyjen metallien välinen korrelaatiokerroin. Maan eri puolilta tulleiden näytteiden tuloksia verrattiin tilastollisesti (Duncan's New Multiple Range Test).

Kotimaisissa näytteissä olivat kuparipitoisuuden vaihtelurajat suuret ja korrelaatiokerroin alhainen. Oulun teurastamolta saapuneissa näytteissä oli suurimmat, muista paikkakunnista merkitsevästi eroavat, $\mathrm{Cu}$-pitoisuudet. Tuontimaksoista todetut pitoisuudet olivat huomattavasti alhaisemmat kotimaisiin verrattuina.

Sinkkiä esiintyi eniten lihasnäytteissä. Lihaksen, maksan ja munuaisten välillä ei havaittu selvää korrelaatiota. Seinäjoen teurastamon näytteissä oli suuremmat $\mathrm{Zn}$-pitoisuudet kuin muissa näytteissä, mutta ulkomaisten ja kotimaisten maksojen välillä ei todettu merkitseviä eroja. Myöskään maksojen lyijypitoisuuksissa ei esiintynyt eroja ja nãytelaatujen välinen korrelaatiokerroin oli pieni. Suurimmat $\mathrm{Pb}$-pitoisuudet todettiin Kouvolasta saapuneista näytteistä.

Kadmium-pitoisuus oli suurin Turun naudoissa. Koko aineiston lihaksen, maksan ja munuaisten Cd-arvojen välillä on selvä korrelaatio, varsinkin maksan ja munuaisten välillä. Sensijaan laskettujen metallipitoisuuksien $(\mathrm{Zn}, \mathrm{Pb}$ ja $\mathrm{Cd})$ välillä ei esiinny korrelaatiota. Tutkituissa maksanåytteissä oli alhaisin pitoisuus australialaisissa näytteissä muiden arvojen ollessa samaa suuruusluokkaa kuin suomalaisten. Elohopea-arvot olivat suomalaisissa näytteissä hyvin alhaiset, joskin Etelä-Suomessa pitoisuudet olivat suuremmat kuin Pohjois-Suomessa. Korkeimmat $\mathrm{Hg}$-arvot todettiin australialaisista ja puolalaisista maksanäytteistä, kun taas irlantilaisten näytteiden pitoisuus oli hyvin alhainen. Kirjallisuudessa esitetyistä tutkimuksista ilmenee, että nautojen iällä on suuri merkitys erikoisesti maksan ja munuaisten lyijy- ja kadmiumpitoisuuteen. Tähän tutkimukseen teurastamoilta saadusta aineistosta puuttuvat ikää koskevat tiedot. Maan eri osien välillä havaitut metalliarvojen eroavaisuudet saattavat osaksi johtua tästä syystä. Tutkimuksessa todetut metallipitoisuudet ovat niin alhaisia, ettei niillä FAO/WHO:n nykyisen käsityksen mukaan ole haittavaikutuksia elintarvikkeiden keskimääräisen kulutuksen perusteella laskettuna. 